Research Report No. 48/2010

\title{
Democracy and Constitutional Change
}

\author{
Allan Hutchinson \\ Osgoode Hall Law School of York University, ahutchinson@osgoode.yorku.ca \\ Joel I. Colón-Ríos
}

Follow this and additional works at: http://digitalcommons.osgoode.yorku.ca/clpe

\section{Recommended Citation}

Hutchinson, Allan and Colón-Ríos, Joel I., "Democracy and Constitutional Change" (2010). Comparative Research in Law \& Political Economy. Research Paper No. 48/2010.

http://digitalcommons.osgoode.yorku.ca/clpe/114 


\section{OSGOODE}

OSCOODE HALL LAW SCHOOL

YOR K UNIVERSITY

\section{OSGOODE HALL LAW SCHOOL}

Comparative Research in Law \& Political Economy

RESEARCH PAPER SERIES

Research Paper No. 48/2010

Democracy and Constitutional Change

Allan C. Hutchinson and Joel Colon-Rios

\section{Editors:}

Peer Zumbansen (Osgoode Hall Law School, Toronto, Director, Comparative Research in Law and Political Economy)

John W. Cioffi (University of California at Riverside)

Lisa Philipps (Osgoode Hall Law School, Associate Dean Research)

Nassim Nasser (Osgoode Hall Law School, Toronto,

Production Editor) 


\title{
Victoria University of Wellington Legal Research Papers \\ Paper No 16/2011 \\ September 2011
}

\author{
Volume 1 Issue No 3, 2011
}

\section{DEMOCRACY AND CONSTITUTIONAL CHANGE}

\author{
ALLAN HUTCHINSON \\ JOEL I. COLÓN-RÍOS
}
This paper can be downloaded without charge from the Social Science Research Network electronic library at:
http://papers.ssrn.com/abstract=1714633
The Social Science Research Network aggregates a list of Victoria University of Wellington Faculty of Law Research Papers at http://ssrn.com/link/Victoria-U-Wellington-LEG.html. Research papers are also listed by volume and issue number at: http://www.victoria.ac.nz/law/research/default.aspx .


Osgoode CLPE Research Paper 48/2010

Vol. 06 No. 11 (2010)

\title{
Allan C. Hutchinson and Joel Colon-Rios
}

\section{Democracy and Constitutional Change}

\begin{abstract}
The relationship between democracy and constitutions is a long and fractitious one. Those who lean towards the constitutionalist side have tended to perceive democracy as a threat to political order and the preservation of important values, whereas those who take a more democratist stance tend to treat constitutions as elite hindrances to popular rule as much as anything else. In this paper, we will give the constitutionalist thesis a broader theoretical and political scrutiny. By way of explanation, we will address and recommend the possibilities and problems for putting into practical operation such an anti-constitutionalist stance; the recent experience of the U.S. State of California offers itself as a good forcing-ground for these ideas. In short, from a democratic standpoint, the challenge for the citizenry is not so much about defining the values of constitutions, but constitutions whose change is outside the scope of popular decision making, supposed to exclusively take place through judicial interpretation or through an amendment formula designed precisely to make change difficult and unlikely. Too often, constitutions place checks and limits on democratic participation in the name of some other set of vaunted truths or elite-favouring values. For the strong democrat, it is formal constitutions and their institutional paraphernalia that do more to inhibit and dull democracy's emancipatory potential than to nurture and fulfil it.
\end{abstract}

Keywords: Democracy, Constitution, Constitutionalist, anti-constitutionalist, U.S. State of California, judicial interpretation

JEL classification: K39

\author{
Allan C. Hutchinson \\ Distinguished Research Professor, \\ Osgoode Hall Law School, \\ Toronto, Canada \\ Joel Colon-Rios \\ Lecturer, Law School, \\ University of Wellington, \\ New Zealand
}




\title{
Democracy and Constitutional Change
}

\author{
Allan C. Hutchinson and Joel Colon-Rios*
}

"Some men look at constitutions with sanctimonious reverence and deem them like the ark of the covenant, too sacred to be touched. They ascribe to the men of the preceding age a wisdom more than human and suppose what they did to be beyond amendment."

- Thomas Jefferson ${ }^{1}$

The relationship between democracy and constitutions is a long and fractitious one. Those who lean towards the constitutionalist side have tended to perceive democracy as a threat to political order and the preservation of important values, whereas those who take a more democratist stance tend to treat constitutions as elite hindrances to popular rule as much as anything else. However, today, the prevailing view is decidedly more constitutionalist than democratist. Theorists, politicians and judges value the democratic worth of popular participation, but maintain that it must be channelled and disciplined within a larger constitutional structure: complicated amendment procedures, judicial review of legislation that is deemed inconsistent with the constitution, and limited opportunities for direct popular involvement in political decision-making. Indeed, far from negating democracy, constitutionalism is promoted as creating an orderly framework within which democracy can be protected and thrive. So contained, democracy will allow citizens to involve themselves more appropriately in political governance and make reasonable political decisions. As crisply stated by the judges of the Supreme Court of Canada, "viewed correctly, constitutionalism and the rule of law are not in conflict with democracy; rather, they are essential to it." ${ }^{2}$

However, although infrequently canvassed and only occasionally championed, the case for a more democratist approach to the challenges of political governance in modern states warrants renewed and more sustained attention. The constitutionalist distrust of popular and active participation in the elaboration and amendment of fundamental laws has been accepted without sufficient challenge; the spectre of mobocracy has been invoked too readily. In this paper, we will give the constitutionalist thesis a broader theoretical and political scrutiny. In

\footnotetext{
* Distinguished Research Professor, Osgoode Hall Law School, Toronto, Canada and Lecturer, Law School, University of Wellington, New Zealand. We are grateful to ${ }^{* * *}$ for their critical comments and helpful suggestions.

${ }^{1}$ Thomas Jefferson, Letter to Samuel Kercheval, July $12^{\text {th }}, 1816$ in THE PORTABLE THOMAS JEFFERSON 558-59 (1975). Of course, he was no 'Saint Thomas' - he wanted to extend the franchise exclusively to white men. See J. APPLEBY, JEFFERSON (2003).

${ }^{2}$ Reference re Secession of Quebec, [1998] 2 S.C.R 217 at para. 78).
} 
doing so, the critical ambition will be to tally the shortcomings of such a stance and to reinvigorate a more democratist approach. By way of explanation, we will address and recommend the possibilities and problems for putting into practical operation such an anticonstitutionalist stance; the recent experience of the U.S. State of California offers itself as a good forcing-ground for these ideas.

In short, from a democratic standpoint, the challenge for the citizenry is not so much about defining the values of constitutions, but constitutions whose change is outside the scope of popular decision making, supposed to exclusively take place through judicial interpretation or through an amendment formula designed precisely to make change difficult and unlikely. Too often, constitutions place checks and limits on democratic participation in the name of some other set of vaunted truths or elite-favouring values. For the strong democrat, it is formal constitutions and their institutional paraphernalia that do more to inhibit and dull democracy's emancipatory potential than to nurture and fulfil it.

\section{THE BODY CONSTITUTIONAL}

A useful point of departure for our analysis is the work of Elkins, Ginsberg, and Melton. ${ }^{3}$ In their recent book, these authors take the traditional constitutionalist stance to its logical conclusion: a concern with the endurance of national constitutions. At the heart of their empirical project is the question "why ... do some constitutions endure, whereas others fail?" ${ }^{4}$ They thus engage in the considerable task of sifting through a data-set that covers every independent state from 1789 to 2005 and that represents 935 constitutions in 200 different nation states. With clarity and subtlety, these authors report that, although the US constitution has endured for 220 years, most constitutions only last a couple of decades: the median life expectancy of national constitutions is 19 years which, as the authors point out, is exactly what a young Jefferson thought was their 'optimal' life-span). ${ }^{5}$ Destabilising factors include economic crises, armed conflict, regime change, territorial realignment, and the like. Moreover, these hazards to a constitution's continued existence are not evenly spread; they are vulnerable early and their demise peaks around 17 years, but decreases until it is lowest around 50 years ${ }^{6}$ For democracies, the average life-span is about 21 years. ${ }^{7}$

While Elkins, Ginsberg, and Melton concede that "there are some real benefits of periodic constitutional replacement" ${ }^{\prime \prime}$ they very much work from the definite assumption that 'a long life is a better life' and that 'survival is success'. For them, a long life-expectancy is the best

\footnotetext{
${ }^{3}$ Zachary Elkins, Tom Ginsberg, and James Melton, THE ENDURANCE OF NATIONAL CONSTITUTIONS (2009)

${ }^{4}$ Ibid. at 2.

${ }^{5}$ Jefferson, supra note 1 , at 560.

${ }^{6}$ Ibid. at 131.

${ }^{7}$ Ibid. at 137.

${ }^{8}$ Elkins, et. al, supra note 3, at 207.
} 
indicator of constitutional health; the longer constitutions live, the better a nation's constitutional health can be considered to be. Of course, there will be exceptions to this, but these only manage to prove the statistical rule. So wedded to this assumption are these authors that they conclude their impressive study with the telling summation that "the life expectancy of constitutions, if anything, has decreased over the last 200 years,... [such that] unlike human beings, the health of constitutions is not getting better with modernity." ${ }^{\prime 9}$ Although this is a disturbing wake-up call for most of the world's constitutional practitioners and theorists, it might be heard by their constitutionalist kin as soothing music to their ears.

Elkins, Ginsberg and Melton's insistence on treating constitutions as if they were people reveals several problems with the traditional constitutionalist concern with constitutional endurance. The first problem is that, even if their physiological analogy is a valid one, it assumes that living a long life is the sole or best measure of a good life. While a longer life is a preferable goal, it is not the only one nor is it the pre-dominant one. For many, the length of life has to be set-off against the quality of that life; a wretched, but long life is not always preferable to a shorter one that is fuller and more rewarding. Indeed, this single-minded focus on extending life-span becomes particularly contentious as people get older. Many have no great desire to be kept alive by all means necessary and make the positive choice not to be resuscitated or be dependent on life-support when their general health and quality of life drops below a certain level. 'Endurance' in itself holds little appeal and often brings with it great concern for the elderly and sick. "Rage, rage against the dying of the light" is not the mantra of everyone; darkness and death can occasionally have their own satisfaction. ${ }^{10}$

The same goes for divorce. While a low rate of divorce might be considered to be more desirable, this is hardly a self-evident or uncontroversial judgement. Like the equation of long life with good health, the choice in favour of 'enduring marriages' demands a degree of balance between quantitative and qualitative considerations. Whether it is better for a couple to stay together come-what-may or to go their separate ways depends upon the standard by which successful or happy lives are to be measured. For instance, it is not apparent that partners and children will lead a more fulfilled life within a warring family as opposed to a separated one. Any resolution of these matters is squarely normative, not merely empirical.

The second problem is it is unclear why it is desirable or useful to treat constitutions as if they were living persons. An analogy is only helpful and illuminating if it has some normative point. While it is possible to compare constitutions to a whole cast of living things (e.g., fruit flies, trees, dinosaurs, etc.), such analogies do little work unless they show constitutions in a

\footnotetext{
${ }^{9}$ Ibid. at 214.

10 DYLAN THOMAS, SELECTED POEMS 131-33 (W. Davies ed. 1974). Although still a controversial notion, there is an international movement that facilitates dignity in dying. See DANIEL HILLYARD AND JOHN DOMBRINK, DYING RIGHT : THE DEATH WITH DIGNITY MOVEMENT (2001).
} 
revealing or novel way. But, without some defence or explanation, the comparison can be as misleading as it is informative. The fact that the US constitution has endured for 220 years is insufficient in itself to warrant praise (or even criticism); the course and content of American history need to be assessed against some independent and evaluative criteria of political success. The implicit standard behind this view is that of institutional order and political stability; the celebration of 'endurance' places these formal virtues ahead of all others. States with old constitutions are in general better than those which change constitutions more frequently.

Elkins, Ginsberg and Melton appear to be indifferent to the need for or appeal of democracy as a guiding political value; democracy is considered to be one of the secondary attributes that might be thought of as instrumental to the continuing life and endurance of constitutions. They report that democratic stability (as opposed to non-democratic governance) is found to be closely tied to constitutional stability and that "enduring constitutions are good for young democracies" ${ }^{\prime 11}$. Moreover, they go on to defend an explicitly constitutionalist approach to national governance. They maintain that:

[C]onstitutions generate a set of inviolable principles and more specific provisions to which future law and government activity more generally must conform. This function ... is vital to the functioning of democracy. Without a commitment to higher law, the state operates for the short-term benefit of those in power or the current majority.... By limiting the scope of government and recommitting politicians to respect certain limits, constitutions make government possible..$^{12}$

In this passage, the authors touch base with all the informing features of contemporary constitutionalism and its ingrained distrust of democracy - inviolable principles beyond democratic reach; limits on democratic participation; constitutions as guarantors of democracy; and the authority of 'higher law'. The basic idea is that, because constitutions are meant to capture not simply a fleeting consensus, but some more universal truths, then no periodic revision of fundamental laws through popular participation is needed or desirable. ${ }^{13}$ Indeed, the extent to which democracy is seen as merely facilitative of and inferior to more significant values and enduring processes is glimpsed by their argument that "democracy is measurably more hospitable to constitutions ... than the authoritarian situation"14 as if this was some recommendation or support for the priority of constitutionalism over democracy. If some regime approximating to an 'authoritarian situation' was more found to be more hospitable, then presumably one should be indifferent to the presence or promise of the democratic ideal.

\footnotetext{
${ }^{11}$ Elkins et. al., supra note 3, at 35.

12 Ibid. at 38.

${ }^{13}$ For an extended critique of this non-democratic philosophy of law and constitutions, see A. HUTCHINSON, THE PROVINCE OF JURISPRUDENCE DEMOCRATISED (2009).

${ }^{14}$ Elkins et. al., supra note 3, at 137.
} 
Of course, this sceptical and frankly begrudging attitude towards democracy is nothing new. Even as there has been frequent and fulsome support for democratic values and processes, there has been a distinct distrust of ordinary citizens' capacity to participate fully, freely, frequently and actively in their own governance. In the twentieth century, democracy came to be associated almost exclusively with the institutional and competitive struggle for people's votes by those leaders who sought political power. ${ }^{15}$ Indeed, a sceptical review of democracy's history suggests that there is almost a disturbing inverse correlation between the extension of the franchise to more groups and a reduction in the amount and areas of power in which the enfranchised can participate: the more that people are allowed to participate as an electorate, the less that is assigned to their decision-making authority. Accommodating prescriptive ideals to descriptive realities, commentators and politicians reduced popular participation to little more than the demand for free and fair elections among multiple political parties in a context of relatively open information: "democracy is government by officials who are accountable and removable by the majority of people in a jurisdiction". ${ }^{16}$ Along with the judicially-enforced protection of basic civil rights, this constrained idea of democracy has come to dominate constitutional law and theory; the goal of a more extensive popular participation seems to have fallen by the wayside. ${ }^{17}$

The main thrust of writings by contemporary constitutional theorists take a similar tack. While they are not hostile to democracy, they do not take its demands or dynamics very seriously; theirs is a cautious and inhibited approach. They concede that democracy is necessary and praiseworthy, but they view it as being far from the animating or central feature of modern constitutional arrangements. There are three basic constitutionalist approaches on offer:

1. A rights-based approach that recommends the permanence of a constitutional regime that is reputed to rest on the 'right' abstract moral principles and political precepts. ${ }^{18}$ With interpretive power residing in unelected and unaccountable judicial pro-consuls,

\footnotetext{
${ }^{15}$ See J.A. SCHUMPETER, CAPITALISM, SOCIALISM AND DEMOCRACY (1947).

${ }^{16}$ JOSEPH NYE, THE PARADOX OF AMERICAN POWER: WHY THE WORLD'S ONLY SUPERPOWER CAN'T GO IT ALONE 109 (2002). This exemplifies the dominant tradition in political theory. See SCHUMPETER, ibid.; ROBERT A. DAHL, A PREFACE TO DEMOCRATIC THEORY: HOW DOES POPULAR SOVEREIGNTY FUNCTION IN AMERICA? (1956); ANTHONY DOWNS, AN ECONOMIC THEORY OF DEMOCRACY (1957); and HARRY ECKSTEIN, A THEORY OF STABLE DEMOCRACY (1961).

17 There is a sub-field of scholarly endeavour which attempts to measure democracy by establishing objective indicators that measure Dahl's contestative and participatory dimensions of democracy. See, for example, DEMOCRACY AND DEVELOPMENT: POLITICAL INSTITUTIONS AND WELL-BEING IN THE WORLD, 1950-1990 (A. Przeworski et al. eds 2000) and David Beetham, Towards a Universal Framework for Democracy Assessment, 11(2) DEMOCRATIZATION 1 (2004).

${ }^{18}$ See, for example, RONALD DWORKIN, FREEDOM'S LAW: THE MORAL READING OF THE AMERICAN CONSTITUTION (1996) and IS DEMOCRACY POSSIBLE HERE?: PRINCIPLES FOR A NEW POLITICAL DEBATE (2006).
} 
citizens and their representatives have little role in such a political regime other than to conform to the almost transcendent authority of this entrenched scheme of social justice;

2. A more representative-reinforcing approach allows to 'the people' the right to have the constitution they want, but does little more than identify the people with the legislature. ${ }^{19}$ Neglecting any actual participation by citizens in constitutional change, any tension between constitutionalism and democracy is attributed to the contested limits imposed by judicial review on the powers of the democratically-elected legislature; and

3. A more populist approach that aims at closing the gap between citizens and their representatives, but it does so at the considerable cost of replacing the messy lives of flesh-and-blood human beings who actually live under the constitutional regime with an almost mythical and disembodied 'People' (always with a capital P) whose collective wishes and interests are to be identified ex post facto and whose decisions are to be protected by judges from the actions of the ordinary representatives. ${ }^{20}$

While each of these approaches offers valuable insights into the dilemmas and demands of modern constitutional polities, they all succeed in reducing or limiting the role of democratic participation - the rights-based approach rejects entirely the idea that all laws, including fundamental ones, must be permanently open to regular transformations through highly democratic procedures; the representation-reinforcing approach takes democracy much more seriously, but fails to appreciate that there is more to democracy and popular participation than majoritarian decision-making through representative institutions and a distrust of judicial review; and the popularist approach for all its good democratic intentions still manages to resist the idea that genuinely democratic constitutional change mandates the actual participation of citizens in constitutional politics, not merely the implied support of the People as divined by an academy of self-appointed experts. By so containing and confining direct democratic participation, the constitution is given priority over democracy. The rough-and-tumble of democratic politics is too risky and untamed for the precious world of these constitutionalists.

\footnotetext{
${ }^{19}$ See, for example, JEREMY WALDRON, LAW AND DISAGREEMENT (1999) and The Core of the Case Against Judicial Review, 115 YALE L.J. 1346 (2006); JOHN HART ELY, DEMOCRACY AND DISTRUST: A THEORY OF JUDICIAL REVIEW (1980); and RICHARD D. PARKER, HERE THE PEOPLE RULE: A CONSTITUTIONAL POPULIST MANIFESTO (1994).

${ }^{20}$ See, for example, BRUCE ACKERMAN, WE THE PEOPLE: FOUNDATIONS (1991); Akhil Reed Amar, The Consent of the Governed: Constitutional Amendment Outside Article V, 94 COLUM. L. REV. 457 (1994); and SANFORD LEVINSON, OUR UNDEMOCRATIC CONSTITUTION: WHERE THE CONSTITUTION GOES WRONG (AND HOW WE THE PEOPLE CAN CORRECT IT) (2006).
} 


\section{Toward a Weak Constitutionalism}

Democracy is about self-government. Its basic idea is that citizens come together as political equals and decide for themselves the laws which will regulate their conduct and the institutions under which they live. As such, democrats are especially preoccupied with sources. ${ }^{21}$ No matter how substantively just a legal principle or rule seems to be, a democrat will always be interested in questions about its origin and, therefore, its legitimacy. In particular, the whos and hows of any established principle or enacted rule will be of compelling interest. A vital dimension in the assessment of any legal norm as just is the fact that it originated in an exercise of self-legislation by the governed, not simply imposed or made on their behalf: democracy is about rule by the people and not only for the people. ${ }^{22}$ However, the democratic pedigree of a law is not the only concern of a democrat: democratic lineage is a necessary, if not always sufficient condition for an initiative's just quality. Both the matter and manner of laws are important. Indeed, it is the procedural mode of their creation that bolsters and underwrites the substantive merit of those laws; matter and manner are intimately related and reenforcing. While this attention to sources has considerable salience in the legislative arena, its implications are even more pressing in regard to constitutional or fundamental laws which, by their nature, are often beyond the reach of day-to-day politics.

The amenability of constitutional arrangements and fundamental laws to periodic reconsideration and revision seems an indispensable part of any democratic compact. Even if it requires some trade-offs and compromises to be put into practice in large societies, strong democracy is a regime of popular self-government which not only allows for, but relies upon the regular participation by citizens in the formulation and enactment of the laws that govern their lives. At its most general, it is the rule of everyone by everyone. ${ }^{23}$ For the democrat, a political system that has entrenched the 'right' abstract principles in what is thought to be a finished constitution and that has attempted to froze in place a particular juridical arrangement sits uncomfortably with any genuine commitment to democracy. Democracy resists political closure; it fosters, not forecloses political and popular engagement: a self-governing people must be able to confront and re-formulate its commitments on a democratic and regular basis. ${ }^{24}$ In that respect, democracy supposes not only ample opportunities popular participation, but a regime consistent with the ideal of democratic openness: there can be no set of laws whose authority is taken for granted and which are not subject to revision.

\footnotetext{
${ }^{21}$ See Jeremy Waldron, Can There Be a Democratic Jurisprudence?, 58 EMORY LAW JOURNAL 675 (2009).

${ }^{22}$ See, for example, Frank Michelman, Constitutional Authorship in CONSTITUTIONALISM: PHILOSOPHICAL FOUNDATIONS 76 (Larry Alexander ed. 1998) and FRANK MICHELMAN, BRENNAN AND DEMOCRACY (1999).

${ }^{23}$ MICHAEL HARDT AND ANTONIO NEGRI, MULTITUDE: WAR AND DEMOCRACY IN THE AGE OF EMPIRE 240 (2004).

${ }^{24}$ Cf. STEPHEN HOLMES, PASSIONS AND CONSTRAINTS: ON THE THEORY OF LIBERAL DEMOCRACY (1995).
} 
While a more democratic position is not indifferent to outcomes and is promoted on the basis that it will result in a more just society, its critical wager is that the governed will produce more outcomes which are more conducive to society as a whole than those dictated by abstract and partial principles or by elite institutions and agencies. As such, it should be clear that the democratic critique is not about a conflict between rights and popular participation, but about the institutionalization of a juridical arrangement that, by embodying certain principles and values, is removed from democratic politics. If democracy is only about right outcomes, and if those outcomes are already embedded in a constitutional arrangement and removed from popular discussion and debate, the ideals of openness and popular participation with respect to the fundamental laws are rendered meaningless. In sharp distinction, a democratist dynamic insists that all arrangements must be open and fluid at least on regular and mandated occasions and that this openness and fluidity is achieved through highly democratic procedures.

While the concern in non-democratic societies to "organize political institutions so that bad or incompetent rulers can be prevented from doing too much damage" is understandable, ${ }^{25}$ it is condescending and inappropriate in ostensibly democratic cultures. By and large, democrats have been thwarted in their efforts to institutionalize the belief that the governed are not only competent to elect their governors, but also entitled to make political judgments for themselves about all, not only some substantive issues. If ordinary laws and especially fundamental laws do not result from the exercise of popular participation, then there may be talk of good or bad laws, but not of democracy. In a robust democracy, everything is always 'up for grabs' and present institutional arrangements should always be open to revision and replacement, albeit not sporadically or haphazardly. It is not a case that 'anything goes', but that anything might go. ${ }^{26}$ With democracy comes risk. But that is both the exhilarating promise and the ever-present danger of democratic governance.

Of course, there is a role for a constitution in such a truly democratic society. But, in contrast to the dominant constitutionalist view, any constitution must be subject to the constituent authority, approval and reappraisal of ordinary people. Any restraints on democracy can only be justified in the name of democracy, not by some other set of supposedly superior values or processes. There is a case to be made for a conceptual and practical re-calibration that puts a weak form of constitutionalism in the service of a strong democracy. Within such a model of constitutionalism, fundamental laws would remain permanently open to democratic transformations and popular interventions. There is no such thing as a 'good' or 'finished' constitution. Nor is weak constitutionalism compatible with the notion that such constitutions might evolve, as most constitutionalists recommend, mainly through constitutional interpretation, ${ }^{27}$ Only such a conception of constitutionalism, when accompanied by a strong

\footnotetext{
25 KARL POPPER, THE OPEN SOCIETY AND ITS ENEMIES (1965) vol. 1 at 107.

${ }^{26}$ See Cornelius Castoriadis, The Greek Polis and the Creation of Democracy in CASTORIADIS READER 282 (David Curtis ed. 1997). See also A. HUTCHINSON, IT'S ALL IN THE GAME: A NON-FOUNDATIONALIST ACCOUNT OF LAW AND ADJUDICATION (2000) and

${ }^{27}$ See Elkins et. al., supra note 3 , at 102-108. See also WILL WALUCHOW, A COMMON LAW THEORY OF JUDICIAL REVIEW: THE LIVING TREE (2007).
} 
democracy, is consistent with a serious commitment to the democratic ideal. However, this supposes that democracy is not exhausted in legislatures and daily governance: it extends to deliberating and deciding on the very content of the constitution itself. In contrast to the 'representation-reinforcing' and populist' approaches, we defend a distinction between democracy at the level of daily governance and democracy at the level of the fundamental laws. By their very nature, each of these dimensions demand and allow different levels of popular engagement.

Any conception of constitutionalism that is more sensitive to the ideals of popular participation and democratic openness insists that a constitution must not be the exclusive domain of elite jurists and professional experts. Because it takes seriously the idea of democracy at the level of the fundamental laws, it does not perceive an active citizenry as a threat to a society's wellbeing, even when its actions might result in the destruction of the established constitution and the emergence of a new one; popular participation is a cherished force for addressing and remediating existing injustices. As such, the idea of constitutions as "bargains among elites" 28 no more than half-right. Because constitutions are 'bargains', they must be open to regular renegotiation as circumstances and generations change. However, this most definitely cannot be achieved by 'elites'. In a democratic society, a constitution is the prize of all and, therefore, must be the property of all; the opportunity to re-negotiate the terms and conditions of the society's basic constitutional compact is a sine qua non of a strongly democratic polity.

So understood, weak constitutionalism comes accompanied by the idea that important constitutional transformations should not be the work of ordinary institutions. Such institutions are designed to operate at the level of daily governance when intense episodes of popular participation are not always practically possible. Weak constitutionalism is not about a constitution that, exactly like ordinary law, can be easily changed by democratic majorities if the term 'democratic majorities' simply refers to a majority of state officials sitting in a legislature. In fact, it requires a degree of openness that is neither possible nor desirable in the context of an ordinary legislature. If a legislature, even if hampered by special procedural safeguards, is granted the ample power to amend or revise the constitution without the active involvement of citizens, democratic legitimacy is adversely affected. Even in the context of a legislature unhindered by the rulings of competing curial forums, it should be ordinary citizens who are accorded the direct power and authority to determine the content of the fundamental laws.

Further, weak constitutionalism rests on an uncompromising commitment to a participating and active citizenry. The citizen is not seen merely as a human being with rights that participates occasionally in politics through the election of officials, but as someone who plays a part in the (re-) formulation of the norms that govern the state. In other words, a citizen

${ }^{28}$ Elkins et al, supra note 3 , at 7. 
contributes directly to the democratic legitimation of the constitutional regime and knows that, despite all the imperfections of such an order, it can be changed. So understood, citizens might identify more with the constitutional regime and think of it as their own, not simply as the embodiment of the collective will of a mysterious People. ${ }^{29}$ When important constitutional transformations are needed, this active citizenry engages in different forms of political participation in order to create the political climate necessary for extraordinary mechanisms to be activated.

\section{Of Constituents AND ChAnge}

The constitutionalist antipathy towards popular participation is evidenced by the prevailing approaches to constitutional reform. The motivating idea is that change should be infrequent because the stability of a juridical order is a primary value to be protected. However, most constitutionalists do concede that a large part of a liberal constitution's legitimacy rests in the fact that it can be changed through judicial means. Consequently, by way of compromise, liberal constitutions tend to make the process of amendment so arduous that few proposals for change are able to meet its stringent requirements. ${ }^{30}$ Moreover, the proto-typical liberal constitution rarely includes mechanisms which increase popular participation during times of important constitutional transformation or crisis. There is little reference to, for example, the election of delegates that deliberate in extra-ordinary assemblies whose proposals have to be ratified in referendums: democratic legitimacy is thought satisfied by the involvement and authority of ordinary representatives. ${ }^{31}$ This effort to regulate transformative shifts not only makes constitutional change difficult and infrequent, but also works to effect a permanent closure of the political. By making all political power subservient to the disciplinary protocols of the constitution and the Rule of Law, it no longer becomes reasonable to speak of important constitutional transformations except after cataclysmic events, such as revolutions and coup

\footnotetext{
${ }^{29}$ For an overview of the discussion about the ways in which an active citizenship can enhance civic virtue and improve the quality of democratic governance, see Frances Hagopian, Latin American Citizenship and Democratic Theory in CITIZENSHIP IN LATIN AMERICA (Joseph S. Tulchin and Meg Ruthenburg eds.) (2007). See also Michael Walzer, The Civil Society Argument in THEORIZING CITIZENSHIP (Ronald Beiner ed.) (1995) and Robert Putnam, MAKING DEMOCRACY WORK: CIVIC TRADITIONS IN MODERN ITALY (1993).

${ }^{30}$ Also, these limits on constitutional reform extend well beyond basic liberties; they include the entire structure of government institutions. The amendment provisions of most modern constitutions underwrite the permanence of the constitutional order. See, for example, Article V of the U.S. Constitution and Elkins et. al., supra note 3, at 99-103. These provisions usually involve a set of requirements that are more difficult to meet than those followed when the constitution was originally adopted. While most constitutions are adopted by some form of majority rule, constitutional amendments are traditionally associated with super-majorities and other obstacles designed to decrease the possibility of important transformations. Some constitutions even place some clauses outside the scope of the amendment procedure, thus highlighting the fear of constitutional change that characterizes constitutionalism. See, for example, Article 79.3 of the German Basic Law.

${ }^{31}$ See Steven Holmes and Cass Sunstein, The Politics of Constitutional Revision in Eastern Europe in RESPONDING TO IMPERFECTION: THEORY AND PRACTICE OF CONSTITUTIONAL AMENDMENT 277 (Sanford Levinson ed. 1995) and Jon Elster, Introduction in CONSTITUTIONALISM AND DEMOCRACY 3 (Jon Elster and Rune Slagstad eds. 1988).
} 
d'états. ${ }^{32}$ Even after those events it is thought that "by making a constitution, the revolutionary forces are digging their own graves." ${ }^{\prime 3}$

Taking their cue from a Madisonian sensibility, constitutionalists recognise the subversive potential of popular participation - that is why they oppose it. For them, popular participation seems by its very nature problematic as it entails sharing decision-making and granting political power to ordinary citizens and non-elitist initiatives. ${ }^{34}$ The 'tyranny of the majority' is perceived to be much more a matter for concern than executive, judicial or minority tyranny. In order to defuse the endurance-threatening capabilities of a more participatory democracy, they offer a place to representative democracy in the constitutional scheme of things so long as it is constrained in such a way as to shore up rather than undermine the constitution's stabilising role. Constitutionalists tend to favour representative government (itself subject to different kinds of limits, one of the most salient being judicial review) precisely because it would work as a bulwark against a more rough-and-tumble popular participation. In short, they half-heartedly embrace popular participation, but only so as to smother it better.

Yet the fact that the contemporary institutions and arrangements considered 'democratic' bear little resemblance to more participatory forms of political organization is not considered a weakness or failing by constitutionalists. Indeed, the present constitutional set-up in Americanstyle governments is promoted as exhibiting the very kind of institutions and arrangements that democrats should defend: the perverse position appears to have been reached in which popular participation is almost dispensable and no longer treated as an essential part of what is considered to be 'democratic'. Under liberal constitutionalism, democracy is exhausted by a constitution that establishes representative government, protects liberal rights, and enables all citizens to 'participate' in government by the episodic election of legislative representatives or through the judgments of their judicial officials. This is an impoverished and disabling idea of democracy and one which has little place for the emancipatory potential of popular participation and democratic openness. But it is also the diluted and defanged democracy of constitutional democracy and its constitutionalist advocates.

In contrast, weak constitutionalism/strong democracy does not see constituent power - the

\footnotetext{
32 See Paolo Carroza, Constitutionalism's Post-modern Opening in THE PARADOX OF CONSTITUTIONALISM: CONSTITUENT POWER AND CONSTITUTIONAL FORM (Martin Loughlin and Neil Walker eds., 2007).

${ }^{33}$ Ulrich Preuss, Constitutional Powermaking for the New Polity: Some Deliberations on the Relations between Constituent Power and the Constitution, 14 CARDOZO L. REV. 635 at 641 (1993).

${ }^{34}$ See Claude Ake, Dangerous Liaisons: The Interface of Globalization and Democracy in DEMOCRACY'S VICTORY AND CRISIS 282 (Alex Hadenius ed.1997); Sheldon Wolin, Fugitive Democracy in DEMOCRACY AND DIFFERENCE: CONTESTING THE BOUNDARIES OF THE POLITICAL 37 (Seyla Benhabib ed. 1996); and Ellen Meiksins Wood, Democracy: An Idea of Ambiguous Ancestry in ATHENIAN POLITICAL THOUGHT AND THE RECONSTRUCTION OF AMERICAN DEMOCRACY (J. Peter Euben et al eds.1994).
} 
underlying and enabling popular agency to create and re-create constitutional regimes ${ }^{35}-$ as something to be muzzled and contained. It embraces the idea that there is a permanent and juridically unsolvable tension between the constitution and the political power which it regulates and to which it owes its existence. Consequently, instead of privileging the enduring supremacy of a constitution that is difficult or well-nigh impossible to change, it recognizes the constitution both as higher law and as open to the constituent power's future re-assertion of itself. By taking such a stance, weak constitutionalism does not seek to resolve this tension. On the contrary, it recognizes it as an inevitable consequence of having a constitution and actually heightens it by giving to citizens the institutional means for acting together and claiming political priority over the constitutional text, even if only episodically. Put differently, weak constitutionalism allows for a viable and vibrant distinction between democratic governance and democracy at the level of the fundamental laws.

When an important constitutional transformation is needed, strong democracy recommends that changes to the constitution be made through an exercise of popular participation similar to that present when the constitution was adopted in the first place. A constituent assembly, composed of delegates commissioned to deliberate about the future of the constitutional regime, is the preferred method through which democratic constitution-making has traditionally taken place. Ideally, such an assembly is convened in a context of strong popular support for constitutional change, with the specific task of altering the constitutional regime, elected in a way that maximizes the participation of all sectors of society, and it is not subject by any limits found in positive law. Although the proposals of a constituent assembly are normally ratified by the electorate before they come into effect, popular participation should not be limited to a process in which experts draft the constitutional text and then submit it to a 'yes' or 'no' vote in a referendum; it must involve a process in which citizens are allowed to propose, debate, and finally decide on the content of their constitution.

The constituent assembly avoids the most salient shortcomings present in the three main approaches to constitutional theory. As a mechanism for the exercise of constituent power, it allows the citizenry to approach the constitutional regime as radically open and susceptible to any kind of modification. As an extraordinary body, it is based on a distinction between the ordinary legislature and the people, between constituted and constituent powers. Finally, its episodical nature facilitates intense popular participation in constitutional change. When triggered by the citizens themselves (e.g., through the collection of signatures), a constituent assembly would facilitate the realization of democracy at the level of the fundamental laws. In fact, it would come very close to embody the ideals of democratic openness and popular participation. On the one hand, a constituent assembly, as depository of the constituent power

\footnotetext{
35 The most famous formulations of constituent power can be found in the works of Emmanuel Sieyes and Carl Schmitt. See EMMANUEL J. SIEYES, WHAT IS THE THIRD ESTATE? (1963) and CARL SCHMITT, CONSTITUTIONAL THEORY ( 2008). For a contemporary discussion of this concept, see Andreas Kalyvas, Popular Sovereignty, Democracy, and the Constituent Power, 12(2) CONSTELLATIONS (2005) and THE PARADOX OF CONSTITUTIONALISM: CONSTITUENT POWER AND CONSTITUTIONAL FORM (Martin Loughlin and Neil Walker eds. 2007); Joel Colón-Ríos, The Legitimacy of the Juridical: Constituent Power, Democracy, and the Dilemmas of Constitutional Reform, OSGOODE HALL LAW JOURNAL (forthcoming 2010).
} 
has no competencies and can make any change in the constitutional regime, no matter how fundamental. It can even result in the (unlikely) abolishment or modification of the rights that make any democratic exercise possible and in the alteration of the very amendment formula that provides for its convocation, although if it does, it would destroy its very democratic legitimacy together with that of the constitutional regime. On the other hand, unlike constituent conventions convened exclusively by the legislature, it recognizes the citizenry as the protagonist of important constitutional transformations from beginning to end.

There is always risk and there is absolutely no guarantee that ordinary citizens, as well as the delegates to a constituent assembly, will be any more or less prone to get things 'wrong' than judges, jurists, or elected representatives. However, the citizenry will not affect to opine in the dubious accent of 'universal truth'. Instead, they will only claim to speak for themselves and not later generations who retain similar entitlement to re-work the constitution. Indeed, Elkins, Ginsberg, and Melton's calculation that the average life-span for constitutions in democracies is about 50 years is perhaps a cause for regret, but not in the way that they think. ${ }^{36}$ If anything, from a democratist standpoint, it is a little too long rather than too short as they imply.

\section{A CALIFORNIAN EXCEPTION?}

If the endurance of constitutions is seen as an important political value, it should not come as a surprise that for most constitutionalists, the US constitution is a thing of wonder. Still manoeuvring strong at 221 years old and with no realistic end in sight, it is held up as the proud exemplar of not only constitutional endurance, but also constitutional merit. As frequently argued, its balanced provisions of specificity, flexibility, and inclusion, its occasional amendment, and its reliance on judicial review to retain its modern relevance have probably contributed to its longevity. ${ }^{37}$ However, why this extended life-span should equate with its excellence is entirely unclear. For many, the fact that it is almost unchangeable by formal amendment is indictment enough. ${ }^{38}$ The stability of the constitutional order cannot in itself be reason enough to support its prized quality. Indeed, from a democratist viewpoint, the resort

\footnotetext{
${ }^{36}$ Elkins et. al., supra note 3, at 137.

${ }^{37}$ Ibid. at 65.

38 David Strauss, The Irrelevance of Constitutional Amendments, 114 HARV. L. REV. 1457 (2001). There are still some U.S. states that require some kind of popular consultation on their constitutional arrangements every number of years. See for example Article 19(2) of the New York State Constitution: "At the general election to be held in the year nineteen hundred fifty-seven, and every twentieth year thereafter, and also at such times as the legislature may by law provide, the question "Shall there be a convention to revise the constitution and amend the same?" shall be submitted to and decided by the electors of the state; and in case a majority of the electors voting thereon shall decide in favor of a convention for such purpose, the electors of every senate district of the state, as then organized, shall elect three delegates at the next ensuing general election, and the electors of the state voting at the same election shall elect fifteen delegates-at-large...".
} 
to informal and elite modes of constitutional re-invigoration, especially through subconstitutional political change (e.g,. executive practice, legislative convention, etc.) and judicial review, has exacerbated an already precarious situation for the vitality of democratic governance.

The present economic and budgetary crisis being experienced by the United States government offers a clear glimpse of the democratic limitations of a constitutionalist approach. In formulating and implementing an effective strategy, the participatory role of the citizenry is extremely distant and removed. Although each claims to represent 'Main Street' and not only 'Wall Street' and to speak on behalf of 'ordinary Americans', the involvement of those ordinary residents of main-street America are conspicuously lacking. Even if there is government for the people (which, of course, is open to debate), it is not by the people. Moreover, not only are the legislative and executive branches of government engaged in an elite and convoluted confrontation of self-interested politics, but Congress is itself viewed by many as entirely dysfunctional in its capacity and willingness to respond in non-partisan ways to national or any other crises. Again, these debilitating traits of centralized and bureaucratic government are on full display over efforts to reform the health care system. On all fronts, the formal and informal structures of constitutional ordering are missing-in-action, power-brokering is the name of the game, and democracy has been reduced to little more than a rhetorical flourish.

The response of constitutionalists might well be that institutional opportunities for a more participatory and engaged exercise of democratic involvement would do little to help and might actually worsen the ability of government to act appropriately. Indeed, they might well point to the trials and tribulations of the U.S. State of California. Already possessed of the most longwinded constitutions in the world, the state is not only fighting its own fiscal crisis, but there have been constitutional proposals for a constitutional convention at which a new formal document would be debated and drafted. ${ }^{39}$ Some allege that it is its very open and democratically-attuned constitutional structure which has worsened, if not precipitated this parlous state of affairs. Along with a participatory procedure for budgetary and tax reform, the villain of the piece is considered to be direct democracy. In the past 100 years, there have been over 500 constitutional amendments by way of voter initiatives and referendums. Constitutionalist critics contend that, while democratic participation is a good thing, too much of it exercised too often can be a bad thing: democracy has its place, but that place must be suitably constrained and balanced by other important values and processes. ${ }^{40}$ For constitutionalists, California has the balance all wrong.

Judged by the standards of fiscal propriety and bureaucratic efficiency, neither a

\footnotetext{
${ }^{39}$ Repair California, the group proposing the popular initiatives, recently announced the need to put the campaign on hold due to a shortage of funds. Not surprisingly, these kinds of initiatives, as well as the very idea of a constitutional convention, are seen with suspicion by the traditional conception of constitutionalism. A good example is the recent New York Times editorial about the proposed constitutional convention in New York. See "The New York Convention Con", Editorial, New York Times (August 10, 2010).

${ }^{40}$ Elkins et. al., supra note 3, at 32, 38.
} 
constitutionalist US governance model nor a democratist Californian governance framework seems to be faring very well. Yet, if these were the only criteria of successful government, it would matter little if there was a monarchical, authoritarian, popularist or any other kind of constitutional arrangements in play; all that would count is the government's ability to respond in the right way to budgetary concerns. However, this suggests that there is some 'right way' to achieve fiscal propriety when there are only different and divergent approaches - balanced budget, social justice, democratic accountability, etc. - to the challenges of public finance policy. The best route to take is not a technical calculation alone, but one that touches on some of the most fundamental issues on the ideological agenda; there is no neutral or nonpartisan position from which to act or evaluate. ${ }^{41}$ That being the case, there is no reason why those decisions should be removed from the political arena of popular participation and left in the hands of the political elite and their armies of technicians and mandarins. As with so many other areas of government responsibility, there is no "higher law" or "set of inviolable principles ... to which future law and government activity must conform ... [and which] make government possible" ${ }^{42}$ And, even if there were, it is unclear why they should not also be open to regular and democratic transformation. Under the existing constitutionalist mind-set, popular participation is limited to the infrequent and inadequate occasions of term-elections (which garner less and less popular support as evidenced by the high rate of abstentions).

Of course, there is no mandate, democratic or otherwise, to recommend that all decisions of government must be amenable to popular and direct participation by citizens. However, and as importantly, there is no reason that the occasions for such involvement should not be increased and made more effective. By ensuring a regular process of democratic engagement, the citizenry might not only develop a better taste and understanding for resolving political challenges, but also begin to take responsibility for the community's problems as well as their solutions; they will have a stake in the polity's political life as well as in its laws. In a strong democracy, a constitution would facilitate and expand such involvement by developing and ensuring that the most fundamental and important matters of governmental policy, including the institutions and processes of democratic participation themselves, would be regularly put to the citizenry for possible re-formulation and resolution. In contrast to constitutionalists, democrats would put their faith in the people's actual views than in the views of a professional elite, even if clothed in the dubious trappings of representative legitimacy, about what is best for people. Democracy is to be the rule in constitutional governance, not the exception.

Consequently, in contrast to the likely constitutionalist apprehension about the present

\footnotetext{
${ }^{41}$ For a critique of the philosophical effort to identify and prioritise enduring or transcendent values, see Hutchinson, supra, note 6 at 11-15 and 129-35. Also, for an introduction of the debate over appropriate standards for fiscal responsibility, see Lisa Philipps and Miranda Stewart, Fiscal Transparency: Global Norms, Domestic Laws, and The Politics of Budgets, 34 BROOK. J. INT'L L. 797 (2009).

${ }^{42}$ Elkins et. al., supra note 3 , at 38.
} 
happenings in California, we maintain that the democratic forces at work there offer a better or, at least, as much a chance as any other set of constitutional arrangement in confronting the contemporary dilemmas of political governance. Of course, there is no guarantee at all that Californians (as any other people) will get it right (i.e., make decisions that receive the approval of the political elite); the recent and continuing struggle over 'gay marriage' is ample evidence of this. ${ }^{43}$ Nevertheless, the Californian citizenry are not claiming to speak in the name of 'inviolable principles' or 'enduring precepts'. They are simply expressing their views at a certain moment in social history which, by the very nature of that fact, can be changed in the normal order of constitutional and political contestation. For this reason, the recent Californian proposal for the first constitutional convention in over a century, whose members would have been ordinary citizens selected randomly by a jury-like process, should have been greeted with democratic enthusiasm. It ought to be a far from dismaying prospect that there will be nothing resembling a Madisonian "assembly of demi-gods" as happened in Philadelphia in 1787 when America's still-surviving constitution was plotted and drafted. ${ }^{44}$ Leaving such important decisions to ordinary people should be seen not as the symptom of an ailing system in need of constitutionalist intervention, but as an encouraging sign of rude democratic health.

The more widespread adoption of popular institutions, like California's 'constituent assembly', would signify a profound break from the $18^{\text {th }}$ century tradition which still holds sway over constitutional theorists and which Jefferson so forcefully criticized - looking at "constitutions with sanctimonious reverence, and deem them like the ark of the covenant, too sacred to be touched." ${ }^{\prime 4}$ By energizing citizens as democratic constitution-makers, it would signal that genuine constitutional change might not only be possible, but might also work to correct existing and present injustices. Accordingly, from a democratist standpoint, the merit of a constitution is to be found not so much in its longevity and its force towards stability, but in its capacity for both democratic participation and constitutional transformation. It is not only whether people can take part in constitutional decision-making, but how easily, how often, and how actively they can do so; there must be adequate mechanisms and processes in place to maximize these opportunities. When it comes to constitutions in democracies, it might be said that 'only the good die young'.

\footnotetext{
${ }^{43}$ Proposition 8 was approved by Californian electors in November 2008 and sought to amend California Constitution in order to eliminate the right of same-sex marriage as recognized by the California Supreme Court in In Re Marriage Cases, 183 P.3d 384 (Cal. 2008). The constitutionality of Proposition 8 was challenged in California courts on the basis that it constituted a revision, not a mere amendment to the state constitution. As such, it could not be adopted through the initiative/referendum mechanism because revisions can only be proposed by a 2/3 majority of the legislature or by a constitutional convention; see Article 18 of the California State Constitution. The California Supreme Court upheld the constitutionality of the amendment, although limiting its effect with regards to same-sex couples married before the amendment was adopted, in Strauss v. Horton, 46 Cal.4th 364 (2009). The constitutionality of Proposition 8 is currently being considered by the U.S. District Court for the Northern District of California in Perry v. Schwarzenegger.

${ }^{44}$ Letter of Thomas Jefferson to John Adams, August 30, 1787 in THE PORTABLE THOMAS JEFFERSON ** (1975).

45 Jefferson, supra, note 1.
} 


\section{CONCLUSION}

The favoured resolution of the constitutionalism-democracy debate is presently that of treating constitutionalism as the embodiment of the democratic telos. Within such a milieu, academic debate has tended to focus too narrowly on the role and legitimacy of judicial review in such constitutional arrangements. ${ }^{46}$ However, this has only served to reinforce the second-class status, at best, of popular participation and civic engagement. In contrast, we have urged that it more constructive to think about the ways in which citizens can relate and democratize the constitutional regime. In that sense, the adoption or rejection of judicial review is not a problem as long as it, like every other institution and principle, is viewed as experimental and open to democratic reconsideration. But, by moving beyond questions about the legitimacy of judicial review, it becomes possible to think about the relationship between constitutionalism and democracy in a new and more emancipatory light.

In particular, it obliges us to look at the relationship between citizens and constitutions and to the means of realizing democracy at the level of the fundamental laws; this is far preferable than obsessing about who should have the final word about the meaning of a constitutional provision. This shift of focus will, of course, raise the political stakes exponentially. And this is no bad thing. Rather than simply determine which of two more or less unrepresentative institutions (i.e., the judiciary or legislature) should enjoy more power, theorists and politicians alike will be obliged to come face-to-face with ordinary citizens in a genuinely democratic encounter. This is a debate and an encounter worth having. In so many ways, not only the United States, but the rest of the world is still looking for its modern-day Jeffersons to help desacrilize constitutional covenants and revitalise the well-springs of popular participation. This would be the wisest and most practical thing to do.

${ }^{46}$ For an effort to move beyond the judicial/parliamentary supremacy dichotomy towards an emphasis on popular participation in ordinary law-making and constitutional decision-making, see Allan C. Hutchinson, A 'Hardcore' Case Against Judicial Review, 121 HARV. L. REV. FORUM 57(2008). 